\title{
Does Comtemporary Orthodontics Comply with Universal Logic?
}

\author{
Hicham Khayat \\ Maitrise Universitaire en Orthodontie et Orthopédie Dento-Faciale \\ Diplôme Universitaire de Prothèse et de Réhabilitation Maxillo-Faciale \\ Diplôme Universitaire d'Implantologie Chirurgicale Orale et Maxillo-Faciale \\ Certificat post-universitaire de Radiologie Tridimensionnelle Dento-Maxillo-Faciale \\ Head of Polyclinique Dentaire Casablanca's Global care department
}

Morocco

\section{Introduction}

Contemporary orthodontic practice is segmented into schools and methods. These divisions within the specialty lay bare the lack of consensus on such fundamental issues as the conduct of the diagnosis, the design of a treatment plan or the fundamentals of appliance's mechanics! Such a situation would not be acceptable in any other medical discipline. Our purpose is to highlight a few inconsistencies responsible for this situation, under the harsh lights of philosophy and history of medicine.

\section{Clinic}

In the late eighteenth century, a new concept of Mankind takes place. Along with the development of sciences, the growing accumulation of knowledge boosted by the advances in printing, and an improved flow of knowledge. By grouping the patients in the same place-the hospital, initially a "mourroir"1, a place where sicks were taken to die, the society, aiming to prevent epidemics, has extracted the patients from their own personal conditions, their homes and their family care; Thus Reducing the variability of forms of the same "disease" mainly related to the terrain; Thus making possible the observation of similarities in different patients. And finally society has created the conditions giving rise to another view, another thought: A new method based on the observation of symptoms and signs, the methodical and comprehensive grouping and consolidation of these "clinical signs"in "tables". This method took place although no one claimed to have built it and deeply contrasted with the previous discurses. The clinical method, that is to say modern medicine was born. It is constituted as a way of thinking opposed to the archaic medical practice. By "Clinique", was meant a "rationalist methodology" of medicine.

This original meaning has been forgotten over time. Many doctors today confuse it with office. This confusion may reflect the fact that in his genealogy, the clinic combines the knowledge, the Sick and the Institutions. As Michel Foucault has shown, its foundations are local, political and institutional factors. When the fundamentals changes, knowledge changes and sometimes loses. The doctors have forgotten the meaning of the Clinic. They 
have forgotten his former discoveries. Worse, doctors have forgotten that they have forgotten, willing to remember no more than the incompressible know-how mandatory to exercise: the technique.

As the clinic was established to accommodate the new, it disintegrates as it is no more than preserving what is already known, a repetition of what is already certain. Moreover, today, among the fundamental basis of contemporary orthodontics, medical marketing in all its forms, plays an increasingly important role.

Any theory always vanishes at the patient's bedside. The first premise of the clinical method is the perfect match between the visible and the expressible. Recovery without rest between the visible and the expressible. This is the logic of Condillac, the vision of a talking eye. With the clinical method, the eye finally cleared of chimeras is ready to welcome the new. And to describe it. Appoint to recognize. Recognize to treat. Probabilistic reasoning will appear and anatomopathology will assign a seat to evil in the very thickness of the living. But the Clinic which is whole based on this unprecedented relationship between vision and language should not be reduced to the systematic collection of signs already described. The "look" of the clinician, in any discipline is, and has to be the basis of any progress. Based on what is known as certain, with an extensive multi-disciplinary vocabulary, the true clinician will find the key point without losing his way gazing to everything and measuring everything. The eye must keep its edge. Beware of habits and systems. Reject the blinders of theory. Stay acute in order to detect the different, the new and the subtle.

\section{Care givers and the principle of rationality}

In preclinical times, men and women took over the health of their community, claiming to enjoy a mythical rationality ${ }^{2}$. The witch healers from prehistoric times invoked the devil. The priests of ancient times interceded for the patient with the divine (Serapis in Egypt, Apollo and Aesculapius in Greece ...). But the church abhorred blood: Ecclesia abhorret a sanguine. The monks of the Middle Ages are striving to console the sick: Question: Why does God allow us to endure such terrible evils? Answer: Because it is expedient for His glory and for the good of our soul. God is purifying its elected. He is not a judge who punishes. He is a father who corrects and chastises his beloved sons. And thus, the evils become great assets. The doctors were, mostly, members of the clergy and therefore unable to practice surgery. Surgery is thereby relegated to a lower rank in society, mainly performed by tooth-pullers, fairground merchants or barbers. They will become our ancestors, the "barber-surgeons", after a long conflict with the organized, educated and Latin-speaking body of physicians. With the clinical method and the more predictable and reproducible therapeutic results it provides, the care giver becomes a scientist. Accused yesterday of mentir comme un arracheur de dents (NDLT: "lying like a tooth-puller") dentists today aspires to an evidence-based practice.

Contemporary Orthodontics is a living example of the decline of the clinic. For many renowned authors, performing a diagnostic is no more than obtaining senseless measures compared to meaningless tables the only justification for which being the fact that everyone uses them. It rejects the individual in a face or a smile, while the clinic was established to the contrary from the individual, to welcome the new far from any dogmatic closure.

Treatments are standardized. As the barber who only deals with bleeding, we simply perform the same techniques reported by few measures and a programmable frame of mind, moving away from the path of Hippocrates who was attached to the observation and despised any form of system. You have to observe and to look askew. As mentioned by 
Michel Foucault, "Looking askew" is a productive intellectual tactic, a must for clinical way of thinking. This is an invitation to observe from a novel standpoint, the intellectual processes by which we assess the functional or aesthetic situation of our patients and transform it into a good outcome through our diagnosis and our treatment.

\section{Seeing, knowing, treating}

Looking askew is the condition of birth of new thinking and relevant mind processes. Learning to see better, to see differently, learning to describe better. This is the only approach that always has and can still allow the emergence of better paradigms in phase with the up-to-date knowledge and cutting-edge technologies. See the subject but also its further investigations. Open to all vocabularies of modern dentistry and more broadly to any exact and universal knowledge.

\section{Measuring, calculating, executing}

In contrario, the "ready to wear thought system", and its inconsistencies, violate the fundamental clinical postulate, veiled the eyes of the practitioner, format his vocabulary and confine his arguments. The technique comfortably installs the practitioner in a robot status from witch that may be difficult to break free. Retreating into its certainties, abdicating critical sens and without curiosity about the fundamentals, the practitioner takes the risk of falling into dogmatism. The speech, the challenges and promises of the Clinic are threatened with extinction in the furrows of the technique and repetition.Today, orthodontic diagnosis is often based on a "fetishist" methodology : The dimensional statistical cephalometry.

Implicitly, this assumes that there is a cephalometrical numerical standard, a geometric "ideal" "canvas which can serve as an étalon to establish a diagnosis, develop a treatment plan and express a prognosis. This contradicts the morphological and biological variability of living organisms. The majority of cephalometric analysis authors has cautioned against the misuse of their own indicators and have sometimes confessed to their arbitrairy. Nevertheless, the ease of the method, compatible with delegation and mass-practice orthodontics has assured its wide spreading among doctors and scholars. In the other hand, a relevant vision of the human head brought by architectural analysis does exists. Here, the clinician's eye look at the pillars, beams, arches and voids that form a functional structure, lively and full of meaning: The scene and spectacle of oral and facial function.

Once and for all, our purpose is not to condemn cephalometry. It keeps sens as a comparative or statistical tool, but to warn against shortcuts ang this kind of magic thinking that transforms a few integers without any clinical signification into a diagnostic panacea. Warn against The Mismeasure of Man. Againt this "eugenic" Violence of caregivers, forcing life-wide "cases" into narrow "boxes". The difference is enormous between a physician who takes the time to observe and one who "reads" labels, pasted on a radiological shadow.The aesthetics, which occupies a central place in the pattern of consultation and the therapeutic purpose is rarely the subject of academic teaching in our specialty. Straight lines, disastrous shortcuts of hurry thinking 4 , hides the faces. Blind clinician Eyes.

\section{Recipes instead of thinking}

We see the tooth moving but, in reality, it is the socket that moves. Mechanics is the essence of orthodontic treatment. The resulting forces at the periodontal interface multiplied by the 
amount of tooth displacement is a mechanical energy than is expressed in joules. Thus, for an equal outcome, the best treatment, the most respectful, may well be that which minimizes the total energy transmitted to the periodontal tissues, labile but delicate. Periodontium, as a biological entity, is blind to the endless sophistications of our self-ligating or heat-memory fireworks. Only count the pressures that stimulate or otherwise degrade it. Primum non nocere.Basically, a force is an active ingredient, similar to a pharmacological molecule. The analogy is fruitful since the application point and direction of a force, as the tropism of a molecule, determines the target tissue. The intensity of a force equals to the dosimetry and the duration of exposure to the setting time. In the state of the art, and unusually for orthodontics, we accept that overdosing, over-treatment or bad prescription are not the key poiny.The debate focuses mainly on "ideal" bracket "information", easy opening, easy closing, etcetera. Magic thinking again. Marketing as the foundation of the clinic.Mechanics is an exact science, fortunately, as every day our lives depends on it. Nevertheless, it is never treated seriously. The vast majority of orthodontic literature figures are senseless from a "mechanical" point of view. Several authors have based upon physicists mechanics and contributed to the successful rationalization of orthodontic's mechanics. Their universal input does not enjoy the same penetration in the professional body that the ready to wear technique. They offen have nothing to sale and therefore no communication budget !

Sapere aude! Dare to think, "cried Emmanuel Kant to his contemporaries to help them break free of the intellectual minority ${ }^{5}$. The field of the unthought in orthodontics is much wider than one might think at first sight. The advent of evidence-based orthodontics in the soil of fetishism and inconsistencies of the specialty is problematic. A cure of common sense is highly indicated. "Common sense is the best shared thing in the world, for everyone thinks he is so well equipped that even those who are hardest to satisfy in everything else do not usually want to have more than they do. And as the diversity of our opinions do not come from what some are more reasonable than others, but only that we conduct our thoughts in various ways, and do not consider the same things "6

\section{Conclusion}

Turning his back on exact sciences and universal knowledge, the contemporary orthodontic practice is locked into normalized and similar techniques. Major Clinical issues are sinking in the furrows of repetition. In this context, the research is often a daily checking of what is already known. Innovations are too often minor improvements of what is already used. It will be interesting to retrieve all the subversive potential of the true Clinical method. Subversive in the truest sense, which is put in reverse, move things, violate the order things establish between themselves, and finally overcome them. It is urgent to move away from dogmatic closure. There hides the promises of the clinic.

\section{References}

[1] Foucault M, Naissance de la Clinique] XXXX

[2] Lebrun S] Se soigner autrefois] Médecins, saints et sorciers au XVII ${ }^{\circ}$ et $X V I I I^{\circ}$ siècles] Histoire.

[3] Gould S.J] The Mismeasure of Man] New York] WW Norton.

[4] Sabot P] L'Expérience, le savoir et l'Histoire dans les premiers écrits de Michel Foucault] Archives de Philosophie 2006 ;69:285-303.

[5] Kant I] Was ist Aufklarung ? Berlinische Monatschrifte, 1784.

[6] Desccartes R] Le discours de la méthode] 1637. 


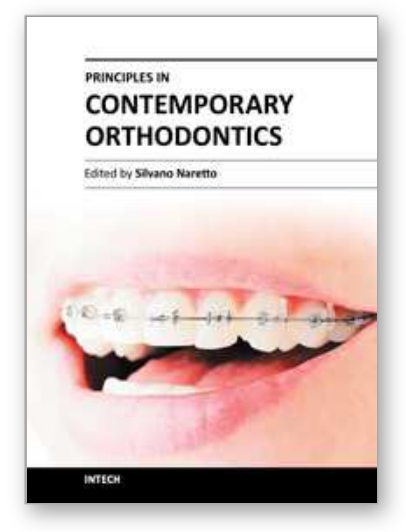

\author{
Principles in Contemporary Orthodontics \\ Edited by Dr. Silvano Naretto
}

ISBN 978-953-307-687-4

Hard cover, 584 pages

Publisher InTech

Published online 25, November, 2011

Published in print edition November, 2011

Orthodontics is a fast developing science as well as the field of medicine in general. The attempt of this book is to propose new possibilities and new ways of thinking about Orthodontics beside the ones presented in established and outstanding publications available elsewhere. Some of the presented chapters transmit basic information, other clinical experiences and further offer even a window to the future. In the hands of the reader this book could provide an useful tool for the exploration of the application of information, knowledge and belief to some orthodontic topics and questions.

\title{
How to reference
}

In order to correctly reference this scholarly work, feel free to copy and paste the following:

Hicham Khayat (2011). Does Comtemporary Orthodontics Comply with Universal Logic?, Principles in Contemporary Orthodontics, Dr. Silvano Naretto (Ed.), ISBN: 978-953-307-687-4, InTech, Available from: http://www.intechopen.com/books/principles-in-contemporary-orthodontics/does-comtemporary-orthodonticscomply-with-universal-logic-

\section{INTECH}

open science / open minds

\section{InTech Europe}

University Campus STeP Ri

Slavka Krautzeka 83/A

51000 Rijeka, Croatia

Phone: +385 (51) 770447

Fax: +385 (51) 686166

www.intechopen.com

\section{InTech China}

Unit 405, Office Block, Hotel Equatorial Shanghai

No.65, Yan An Road (West), Shanghai, 200040, China

中国上海市延安西路65号上海国际贵都大饭店办公楼405单元

Phone: +86-21-62489820

Fax: +86-21-62489821 
(C) 2011 The Author(s). Licensee IntechOpen. This is an open access article distributed under the terms of the Creative Commons Attribution 3.0 License, which permits unrestricted use, distribution, and reproduction in any medium, provided the original work is properly cited. 